International Journal of English Literature and Social Sciences
Vol-6, Issue-1; Jan-Feb, 2021

\title{
The Politics of Migration in Caryl Phillips's A Distant Shore and Chimamanda Ngozi Adichie's The Thing Around Your Neck
}

\author{
Nfon Rita Gola
}

$\mathrm{PhD}$, Department of English, University of Ngaoundere, Cameroon

Received: 02 Dec 2020; Received in revised form: 16 Jan 2021; Accepted: 01 Feb 2021; Available online: 09 Feb 2021

(C2021 The Author(s). Published by Infogain Publication. This is an open access article under the CC BY license

(https://creativecommons.org/licenses/by/4.0/).

\begin{abstract}
Caryl Phillips' A Distant Shore and Chimamanda Ngozi Adichie's The Thing Around Your Neck present migrants cut in the complexity that defines the current global age. This paper accordingly uses the above texts to investigate migrants' existence in the western spaces of Britain and America while most importantly, highlighting the mechanisms they use to survive. The paper again notes how the selected texts fit migrants in planes that concurrently involve conflict and cooperation. It subsequently examines the dynamics of globalisation reiterated in the fact that the practice envelops all the planet, yet allows diverse cultures to project themselves. It uses as theoretical guide globalisation in projection of the theory's proposition that because human beings have alienated from selves and become others, inclusive models should define the human society. The central thesis of this article is that increased migration has ushered in a new epoch which contests difference and obliges humanity to construct holistic manners for the betterment of the human race.
\end{abstract}

Keywords-Migration, difference, cooperation. globalisation, society.

\section{INTRODUCTION}

Literature has for long cross-examined the mobility of populations, goods and ideas across geographical borders. Contemporary literary works successively capture an increase in displacement and relocation. These practices notably relate migration to the swelling economic, social and technological information activities spanning the globe. The outcome of these diverse forms of global networking as Peter Kivisto (2001) notes, is a multicultural society which calls for creative dialogue among the varied races constitutive of the human society. Contrarily to Kivisto's expectations, several complex and diverse concepts exist in concord with this new reality. This obscurity as migration literature recaps, mostly revolves around the lives of migrant subjects. The complication springs from the fact that migrant subjects though are already experiencing dislocations from migration, are obligated by their host spaces to live lives beyond clashes. This is a conforming process which many of them struggle in vain to go through as the new space either rejects them or their old selves keep them tied to their original spaces.

The paper x-rays race, ethnicity, and class as the principal causes of migrants' disillusionment Because of these bordered spaces characteristic of host places, migrants become victims of disenchantment. Though some of them get used up by the above differences, others overcome the sectarian principles and become flag bearers of the universal age. The essay hints on the entwined relation between migration and globalisation. This complexity is X-rayed in migration's functioning as both a process and a push of the globalisation process. The selected texts both highlight difference as a feature typical of migrant centers. Conversely, A Distant Shore highpoints the beauty of immigration only in cosmopolitancy while The Thing Around 
Your Neck articulates the positive effects of migration from the angles of cosmopolitancy and transnationalism. While cosmopolitancy highlights the political and ethical behaviours that are typical of hybrid societies, transnationalism underlines migrants' trans-border activities. Both practices nevertheless, pinpoint human efforts at peaceful coexisting in today's multiracial/multicultural world. Globalisation theory in its profiling as a string of ideas generated by the integration of indigenous cultures consequently projects itself as analytical tool for the paper.

Karl Deutsch (1957) as underscored in Farhang Rajaee (2000:91) builds on the fact that the globalization process has created a human community that is ironically defined by individualistic threats. From this thesis he theorizes that the contemporary world is void of peace. To build a peaceful world, he holds, globalization has to cultivate an inclusive tenet; that which to Eric Cazdyn and Imre Szeman (2011:7-8) has to be the product of "common sense". This sensibility as they clarify, is the desired globalization tenet because it.is a severe voice that restraints society from doing that which is perverse. Globalisation theorists call for mankind's application this good sense. Apparently, it will liberate mankind from the filth of the self and other concepts. As a globalization tenet thus, common sense advocates the negotiation of difference and helps individual to see in others mirror images of themselves.

Both difference advocating and difference negotiating as Jean Bethke Elshtain (1995:81) explicates, are practices typical of the current global world. Difference advocating as Elshtain expounds, is offensive because it creates "politicized" atmospheres where self-interest reigns. Difference negotiating on its part, projects the "political" which entails liable behavior. The theorist consequently portrays the political as common sense and as the supposed voice for the current globalised world. Because the selected texts highlight Elshtain's perceived "politicized" and "political" atmospheres as likelihoods in migration, the paper explores both identities in relation to migrant subjects. The politicized plunge migrants into deplorable atmospheres where they undergo both physical and psychological torture. Contrarily, the political stabilizes the self, and creates an atmosphere where difference instead, radiates a beauty that is worth living with.

\section{THE POLITICIZED PLANES OF MIGRANTS}

As afore mentioned, the local has remained very active despite glaring proves that the earth is actually becoming a global village. Migrancy evokes this treatise in migrants's posing for difference. Their presence anywhere, ignite the sectarian principles inherent in human beings and human society. Caryl Phillips and Chimamanda Ngozi Adichie's migrant statuses serve as credentials for their effective articulation of migrants' personal experiences in the selected texts. While Phillips is a British national of African descent and Caribbean nativity, Adichie is a Nigerian who from the age of nineteen has lived a life, transcending the borders of Africa and the United States of Africa. A Distant Shore expounds on how the Caribbeans, like Africans in the motherland, have remained second hand citizens due to colonial influences. In The Thing Around Your Neck, Adichie explains how Europeans migrated into her native land and forcefully implanted strange ways that have torn the people apart. Both writers highlight in their original spaces, a rootlessness that has become reason for their countrymen's' continuous emigration in the search for greener pastures. Both texts, like Dustmann and Weiss's (2007:2), underline economic incentives, motives related to persecution, and the desire for personal development as the main reasons why people migrate. Equally, both texts debunk the utopia encoded in migration as their works depict migrants in crisis in the western metropolises of Britain and the Unite States of America respectively.

Phillips begins A Distant Shore with a note on how Britain is gradually adhering to the socio/cultural changes occurring on the planet. London has become a migrant center. New arrivals are streaming-in in search for home. The Asian migrants, Said and Mahmood, constitute a part of the new arrivals. As a western educated Asian, Said had thought of himself as a universal intellectual, (what the British who colonized Asia made the Asians to believe) who was free to swoop up jobs in the British society. Instead he finds himself being set up by a British couple, mishandled by the British police and sent to prison where he dies "like a dog"-to use Gabriel/Solomon's words. Phillips, here, like Stuart Hall (1992) underlines that national cultures manifest a strong sense of identity by alienating themselves from other cultures; an accession that underpins the perverse behavior of the British couple towards Gabriel/Solomon.

Correspondingly, Gabriel/Solomon's flee from the troubles of his war torn African country, with the hope of finding salvation in England yields him disappointment. In England, he lives a life of solitary confinement as racists declare him an outsider. His disillusionment is envisioned in his words to Dorothy Jones (a displaced English in England); "This is England. What kind of place did I come to? Can you tell me that?" (p.36). England, his imagined home is just another 
cancerous society. It is peppered with all sorts of social ills. Gabriel/Solomon cannot understand why his colour (black) renders him an element of mistrust and ridicule to the English folk (white race) despite the fact that he has putting in his best for the betterment of the English. Besides being a security man at Stoneleigh, he provides voluntary driving services to a hospital. Unfortunately, he still reminds the "other" to these people and ends up meeting his death in England: the very fate he tried to keep away from by leaving Africa.

Surprisingly, Phillips exposes, through the fifty-five-year-old English Teacher, Dorothy Jones that the English themselves are restless and frustrated within England. She had to leave Birmingham where she was stressed and frustrated by an unfulfilled marriage and the thoughts of having seen her father abuse her kid sister severally. But her migration to the new establishment of Stoneleigh up the hills of Weston village have not helped her. Her move to his village situated "five miles outside her home town" (p.236) was in search of a relaxed atmosphere. Unfortunately, she meets with discrimination from her kin (the English) and consequently, experiences extreme frustration as she explains to Gabriel/Solomon "I don't think they care about anybody apart from their stupid selves" (p. 52). Equating her imagined disposed state to that of Gabriel/Solomon, she continuous, "if this is true then I too may as well be living at the dark side of the moon" (p.52). Gabriel/Solomon had already observed this strangeness in the English as the narrator briefs, "To Gabriel's eyes, English people look unhappy" and "walk with their heads down as though determined to avoid one another ( $p$. 13). This is anti-social manner and it alerts the new comer of the strangeness of his/her new society.

Unexpectedly, a fragile love relationship between Dorothy and Gabriel/Solomon becomes their refuge in England. From the perspective of the English new comers either a people whose prime motive is to exploit them or they are a worthless people running away from responsibilities in their villages/ countries. Dorothy now rates England as an evil society void of justice and the respect of human rights and, consequently, as a country to move out of. She has come to the conclusion that England holds nothing good for her she tells the reader: "For the first time I want to leave England. To see Spain or Italy, England has changed" (p.54). Phillips presents Dorothy as both culturally and socially estranged from England. Like the other migrants who fled their countries in search for the utopian, she too believes that what she wants can only be had out of England. Phillips's A Distant Shore consequently underlines that deferred dreams come with immigration; an ideology that becomes more mind- engaging when Adichie's stories in The Thing Around Your Neck, equally, depict the migrant in physical and psychological stress.

In the story "The Thing Around Your Neck", the Nigerian American Lottery winner, Akunna's dreams of fostering her education, sending gifts home and owning a house plus a car within a short stay in the U.S.A proves elusive. It surprises Akunna that her American uncle wants her to be his mistress before he can help her. As he elucidates prostitution will empower her faster than any other activity and it is the highest female empowering activity in Africa and America. an activity that is empowering women in both Africa and America. Akunna's refusal of uncle's offer sends her out of the comfort of uncle's home. She moves to another American suburb, Connecticut, where she survives by selling in a restaurant at an agreed allowance of a dollar less than the normal wage rate. She rents a "small carpet stained room" and can only study by following up online courses at a library. Her life becomes a nightmare as she does not even have someone with whom to share her plight.

Similarly, in "The Arrangers of marriage", the newly married bride, Chinaza, leaves Nigeria for America with the dream of settling down comfortably with her supposed doctor husband, Ofodile. It was equally supposed that Ofodile was earning a lot of money as a medical doctor in America Unfortunately, she meets with poverty in this new setup as Ofodile's African level of education positions him as an "intern" (p.174). In this condition he is "paid twenty-eight thousand a year" but works "eighty hours a week. Obviously in a bid to let the reader feel his plight he clarifies his financial situation thus, "It's like three dollars in an hour" (p.174). With this amount Ofodile lives in the immigrant neighborhood of Flatbush, a place he plans to abandon when he starts operating as a full time doctor. Only the hope of soon meeting up with America's requirements for citizenship sustains Ofodile. His house is a poorly equipped two tiny bedroom apartment with an offensive smell. Chinaza's determination to remain his spouse comes to an end when she discovers that her new husband had faked a marriage with an American lady who at the moment was threatening him hell for marrying another woman behind her back. Chinaza abandons Ofodile's apartment and settles elsewhere still in search of happiness- that which Aristotle believes every human action sets out to realize.

In "The Shivering" the determination to avoid social ills and the desire to acquire knowledge are the main reasons why Nigerians leave their country for the United States of America. Greed is the main cause of all the ills perpetuated in the Nigerian society. Because of the self-centeredness manifested by Chinedu's homosexual partner, Chinedu 
abandons him in Nigeria and smuggles self into America in search of a state of quite. But America becomes that place where one cannot live peacefully especially without official papers. When his immigration papers expire, the fear of being deported sends him into seclusion. He evades all questions that could invite the suspicion of his illegal status. The Bible becomes his source of comfort. Ukamaka and Udenna, on their part moved to America for studies. But studying at Princeton entails overcoming many challenges including the poor housing facilities and the boring study environment. Ukamaka describes the foreign students residential lodge where she lives as an ugly and charmless square structure. This is a place she is beginning to like, just, because, Udenna, another Nigerian student in Princeton believes the house is not ugly. But to this same Udenna studies at Princeton school campus are so boring that he will have to relief himself from such by completing his studies and return to Nigeria sooner than expected.

Even the Africans in America have forgotten the social code of conduct which talks them into being each other's keeper. The story, "The Shivering" stresses on how the Nigerian migrant, Tobichi, is oppressed and subjugated by his Nigerian employer in America. But Tobichi still braves this challenge with the hope of achieving that which he came in pursuit of. The African no longer shares in the joys and sorrows of his fellow Africans! This perversity is no doubt an indication that happiness has evaded them.

Both texts paint migrant centers as imperfect places in need of improvements. Gabriel/Solomon gives the reader a clue to what is wrong in England thus; "The English think they are superior so they do not care about us." (p.155). From every indication, the concepts of "self" and "other" define the relations between migrants and westerners. Worse still, these concepts are applicable in the way some migrants view each other. This atmosphere images Eric Cazdyn and Imre Szeman's (2011:5) view of globalization as a conceptual project that promotes capitalism in a concealing manner. Besides, Phillips and Adichie, have obviously echoed through their migrant subjects, their silences in the metropolitan centers of the west. Difference, as their texts hold, cannot respond to the challenges of living together. This is obviously a signal that mankind has to articulate new ways that will make sense of the current global society.

\section{THE POLITICAL PLANE OF THE MIGRANT}

Through migration the globalization process is not only affecting all aspects of life and regions of the world in multifarious ways but it is necessitating that humanity adopts values that reflect this atmosphere. The migrant has become the flag bearer of this new way of life. As afore mentioned, migrants are members of the global community given the fact that they live in worlds with no fixed geographical boundaries. Because they are concoctions of past and present selves, their existence manifests cultural mix as they have shaded off that which uniquely define them and embraced fragments of others. The texts under study depict migrants accepting difference, negotiating it and reconciling it for their good and that of the others. This is politics., an activity which David Easton (1953:129)) explains, is the deed of allocating resources to the satisfaction of everyone in the community. Its essence, as John Gaddis (1999: 74) posits, is the effective distribution of resources. To globalization theorists the complex culture generated by migrancy is the right norm for the ongoing global age. Andrew Smith (2004:247) explicates the importance of this culture from the perspective that mankind now lives in a world that has neither fixed centers nor clear-cut boundaries on things. This is an angle of discourse that Phillips A Distance Shore and Adichie's The Thing Around Your Neck project in their presentation of migrants.

Political manifestations in A Distant Shore include the African migrant, Gabriel/Solomon 's application for asylum in a southern English village, his adoption of a new name, Solomon, and the uncommon friendship between Gabriel/ Solomon and his English lawyer Katherine. The issue of asylum here highlights, both, the unprecedented expansion of the scale of illegal migration and the hospitality of the English government towards illegal migrants. Gabriel/Solomon has to be housed, fed and clothed by the government of this locality until his papers will go through. But because of the trouble sparked by his attempted rape on the English girl, Denis he has become enemy of the English. His English lawyer, Katherine conscientises him that he can only escape these newly acquired enemies by taking up a new name and leaving that locality. Correspondingly, Gabriel/Solomon negates himself both by taking a new name and by moving from this English locality to another distant one, in respect of Katherine's advice. He becomes Solomon Bartholomew and journeys through London to the North of England for rehabilitation. Katherine's astonishing friendship with Gabriel/Solomon highlights her cosmopolitan sensibilities, those susceptibilities which (Appiah 2007: xii) hold, are ways and beliefs that lend meaning to human lives. Her behavior saves Solomon from xenophobic hoodlums and kindles the beauty in migrancy. Both Solomon/Solomon and Dorothy defy boundaries and comply with Andrew Linklater's 
(1998:.91) globalisation proposition which states that individuals have to submit to values that are universally valuable.

In the questionable friendship between Dorothy and Gabriel/Solomon. Phillips highlights the complex engagements that migrants enter into, in the quest for survival. Though these two are separated by colour, age and socio/cultural pasts, their isolated states in the host space bind them together. From the negative stare that Dorothy's kin, the English directed against her; "as if she had the mark of Cain on her forehead" (p.6), she understood the plight of Solomon, the African. She made a move towards the young comprehensive Gabriel/Solomon, for an alliance of convenience. Dorothy tuned and encouraged the informality in their relationship as can be read in her words to Gabriel/Solomon, "For heaven's sake, I keep telling you to call me Dorothy. I don't employ you" (p.28). This direct application for Solomon's friendship stops Solomon from calling Dorothy Mrs. Jones and creates a conducive atmosphere between the two. She configures a beauty in Solomon's manners that destroys the ugliness his dark appearance formerly conjured. Her sincere love for Gabriel/Solomon can be seen in the fact that she almost goes mad at his death. Dorothy confesses this love to her parents at the deceased Gabriel/Solomon's burial, thus, "I say I could tell that Solomon is a man who could have made me happy" (p.56). This is a note that Solomon, unlike Brian, her exwhite husband, loved and respected her.

Dorothy, accordingly, transcends xenophobia and embraces happiness in this love for a black man. Her negotiating skills place her beyond the dangers David Held's (2003:4) envisions in fixed identity brackets: to a new realm where she coexists peacefully with the black race. It is again beautiful to observe the already settled Irish migrant Mike rescue Gabriel/Solomon during the latter's hitchhiking through the South of England to the North to his home. Aided by this new family, Gabriel/Solomon becomes a resident of the area-the new settlement of Stoneleigh in the village of Weston. He makes himself useful to the community by watching over the locals and offering voluntary driving services to the hospital. Though no object in Gabriel/Solomon's Stoneleigh bungalow can give one a clue to his origin, he cannot dissociate his mind from his past. He constantly dreams about Africa, especially his terrible past though he has resigned from his violent ways in a bid to promote peace with the locals. But the English still sent him parceled razor blades for letters and shamelessly pushed human faces into his letter box; messages Gabriel/Solomon, in his tolerant nature interprets as "love letters" coming from people "who do not want me in this palace" (p.37).

In Adichie's story "The Arrangers of Marriage" the African migrant in America, Emeka, Ofodile becomes Dave Bell so as "to be as mainstream as possible" (p. 172). Being mainstream, as Adichie explores, implies doing things the American way; which embodies speaking the American English, eating American food, being educated the American way and even marrying an American spouse. Thus, the price for incorporating into the American society is high but most migrants always pay. Ofodile does not only adopt a new name, Dave Bell, but goes as far as marrying an American lady as he tells his new African wife, Chinaza: "It was just on paper" (p.183). This type of marriage, as Ofodile posits, has become a normalcy in the American society. He x-rays the emptiness of this type of marriage-by describing it as a legal contract between an American citizen and a non-American that benefits the American financially and sexually but helps the non-American to become grounded in America. Ofodile advises Chinaza to belong to America by speaking American English by cooking as well as eating only American ditches. This is a schizophrenic frame which entails sacrificing the familiar for the unfamiliar. In conformity with the above, Ofodile a doctor with medical qualifications from an African university is again undertaking the medical education in America so as to qualify for medical practice in the American society.

In the story "The Shivering" Adichie underlines migrants as world citizens caught in between their past and present values and are unable to stick to just one of them. The African migrant Chinedu, does not eat the American dish "Sushi" (raw food) with the excuse that he is doing things the African way. Paradoxically, he eats the American Chemically produced vegetables that is not eaten back home. His defense here is that chemical food is cheaper than organic vegetables and that the chemical in artificially produced food is better than the one in the medical drugs that human beings consume. Interestingly, a majority of Africans in America hate the chemically produced vegetable and instead eat organic vegetables in reflection of what is eaten back home. The reader will obviously question Chinedu's sincerity in positioning himself as an African representation; as a symbol of what Africans do or not do. But his logic in protecting his behavior sends out the message that despite his willingness to live like an African man in America, his financial level delimits him. Cultural globalisation theorists will, however, rationalize Chinedu's manners under the banner that migrants, selectively copy the way of life of their host countries. 
Unlike Philips's A Distant Shore, Adichie's Stories in The Thing Around Your Neck interestingly probe migrant figures engaging themselves in diverse activities back home for psychological relief. She reveals that her ability to communicate with her family brought to an end the psychological distress she had suffered for long. "The Thing Around Your Neck" reveals that because of Akunna's desire to help family back home she compromised many conditions. She monthly mailed "half of her "earnings" (p.118) to her parents in Nigeria. Again, she accepted the love request of a rich white boy, despite his seemingly insincere considerations for her and her hatred for the white race. In "The Shivering" also, Adichie projects the above international spirit in the migrants, Chinedu and Ukammaka who though in America, got actively involved in two unhealthy events in Nigeria the same day they happened. Ukammaka spent that morning on the internet reading Nigerian news" and on the telephone, "calling her parents" (p.142) to get specific details concerning the events. These cross-border activities unquestionably function as transnational ties. To Adichie's migrants, as Thomas Faist (2002:216) explicates, remittances are both a moral responsibility and a mutual commitment to family members back home. Their awareness of homes out there to attend to, enable them to live in new spaces without embracing all what these host spaces entail.

\section{CONCLUSION}

The article used Caryl Phillips's A Distant Shore and Chimamanda Ngozi Adichie's The Thing Around Your Neck to underline migration as a stimulant to both the rapidly globalizing world and the complex identities typical of migrant centers. The migrant centers under study, namely, Britain and America, were analyzed as border loaded spaces significant in their roles as manipulators of migrants original dreams. Multicultural in scenarios, they enlightened migrants on the disadvantage of according meaning from single frames. Migrants subsequently fought the conflicts induced by the varied behavioral patterns in human nature and social constructs to form meaningful spaces for themselves and others. In varied ways they mediated difference in the host spaces and in multifaceted ways they participated in the activities of their home countries. The article however makes naught the utopia inherent in the narrative of migration given that within shaped edges migrants suffered from loss of orientation. Instead it reveals that migrancy conjectures globalisation which has not eliminated the contradictions and confusions definitive of the human society.

\section{REFERENCES}

[1] Adichie, Ngozi Chimamanda. (2009). The Thing Around Your Neck, Lagos: Onikan.

[2] Appiah, Kwame Anthony. (2006), Cosmopolitanism: Ethics in a World of Strangers, New York: www Norton \& Company,

[3] Deutsch, Karl. (1957). Political community and the North Atlantic area: International Organisation in the light of Historical Experience. Princeton: Princeton University Press.

[4] Cazdyn, Eric \& Szeman Imre. (2011). After Globalization. United Kingdom: Blackwell Publishing Lt.

[5] Dustmann Christian \& Yoram Weiss. (2007)." Return Migration: Theory and Empirical Evidence from the UK". In British Journal of Industrial Relations, 45 (2), 236-256.

[6] Easton, David. (1953). "The Political System: An Inquiry into the State of Political Science." In American Political Science Review, 47, (3). Xxiii-320.

[7] Elshtain, Bethke Jean. (1995). Democracy on Trial. New York: Basic Books.

[8] Faist, Thomas. (2002). "Extension du domaine de la Lutte": International Migration and Security before and after September 2001. https://doi.org/1111/j.1747.7379.200265x.

[9] Gaddis, John Lewis. (1999). John Lewis Gaddis: The PostCold War World". In President's Series. 71 https://digitalcommons.odu.edu/pls/71.

[10] Hall, Stuart. (1994). "Cultural Identity and Diaspora". In Colonial Discourse and Postcolonial Theory: A Reader. (Ed.) Patrick Williams \& Laura Chrisman, New York: Harvester, pp.393.

[11] ___ (1992)." The West and Rest: Discourse and Power". In Formations of Modernity. (Ed.) Stuart Hall \& Bram Gieben, Cambridge: Polity, 276-318.

[12] Held, David. (2003). "Building Cosmopolitanism for Another Age". In Conceiving Cosmopolitanism: Theory, Context and Practice. (Ed.) Vertovec Steven \& Cohen Roben, Oxford: Oxford University Press.

[13] Kivisto, Peter. (2001, March).” Social Spaces, Transnational Immigrant Communities and the Politics of Incorporation" https:///doi.org/10.1177/1468796803003001786.

[14] Linklater, Andrew, The Transformation of Political Community: Ethical Values of Post-Westphalian Era, Oxford, Polity Press, 1998.

[15] Phillips, Caryl. (2003). A Distant Shore. London: Faber\& Faber.

[16] Rajaee, Farhang. (2000). Globalisation on Trial: The Human Condition and Information Civilisation. Carleton: Carleton University Press.

[17] Shaw, Martin. (1997). "The State and Globalisation: Towards a theory of state transformation". In Review of International Political Economy, 4(3), 497-513.

[18] Smith, Andrew. (2004). "Migrancy, Hybridity, and Postcolonial Literary Studies". In The Cambridge Companion to Post Colonial Literary Studies, pp.241-261. 